\title{
A conversation on the intangible with Juan Manuel Palerm
}

\section{Paolo Picchi}

Research group High-Density Energy Landscapes,

Academy of Architecture, Amsterdam University of the Arts, Netherlands paolo.picchi@ahk.nl 
During the last three years of research conducted by the Amsterdam Academy of Architecture, we frequently reflected on the intangible values of the landscape. Our research group focuses on the spatial dimension of renewable energy development with a focus on those landscapes where population density is high and where apparently the space to develop renewable energy is scarce. Three years ago, we started a partnership with the Municipality of Amsterdam to develop design thinking to implement at local scale the regional energy strategy plans. The Municipality aims at strengthening daily practices to advance the energy transition. For this purpose, the partnership foresees a training program (the Masterclass High Density Energy Landscapes) whose approach and learning goals have been already described in this journal in an article appeared in 2020.

Current wind energy planning in Amsterdam is developed through external consultancy by offices that make use of automatic cartography tools which address exclusively quantitative parameters as for example distance from infrastructure, inhabited areas, cultural heritage. Planning lacks qualitative local knowledge and consequently plans are completely de-touched from reality causing scale and level mismatches. Among the other knowledge levels, what is missing is the intangible experiential value of the landscape, yet so important whenever we plan and design a transition that in such metropolitan landscapes is going to modify the living conditions of people. Therefore, each year during the masterclass we take municipality officers and planners of the regional strategy in deep landscape immersions, to skip for one week the official mapping. Borrowing Georges Perec's words in his book Specie of spaces ${ }^{2}$, the creativity step of these landscape immersions consists in an almost "situationist" approach ${ }^{3}$ : forgetting what the official land use maps and present planning say and opening new insight on not officially available spaces, and the alternative use and values that citizens make of them.

In the last three years we encountered a wide variety of not officially defined urban spaces, yet spaces already used by citizens or potentially: first we interrogated ourselves on the intangible experiential value of those and second on the energy potential. In synthesis we inverted the current order in energy transition planning and design, based on energy potential calculation first and the reduction or mitigation of the impact on the landscape then (Fig. 1). Recurrent open ended research questions have been: are those spaces relevant for the complex of the social and ecological networks and systems in the area? What is the current and not regulated use people do of this space? What do they feel and val- 

future. In the atelier we therefore departed from the hypothesis that communities can 'cultivate' renewable energy through a garden metaphor ${ }^{4}$, so in harmony with the cultivation of ecologies, food, archaeologies, aesthetics and narrative. Being there, what better occasion to have a conversation with Juan Manuel Palerm? ${ }^{5}$ The conversation focuses on the topic of the intangible in the $21^{\text {st }}$ century challenges and aimed to expand the discussion on the way to approach the intangible values in such complex transitions.

At the beginning of the conversation, we asked to Juanma whether the intangible values of the landscape are crucial to face future transitions and what have been his last experiences in designing with them. Yes of course the landscape of contemporaneity despite modern times have intangible values that deserve our attention, and that derive from a contemporary way to look at the world. During modern times the main idea of the world was human centrality, the world was rotating around an idea, a position of the man facing the world and if we think about Brunelleschi and his doom we can intuit the physicality of this approach, there is no place for the intangible, the landscape is tangible, coincides with a strong idea and is human made.

Juanma continues and says that in current times is different, our current sensibility to the landscape issues brings the intangible values to a prominent position. He reported on two last experiences through two authors he does appreciate and that inspire him. The first author is the Spanish Pedro Garcia Cabrera, author of the book El hombre en función del paisaje $e^{6}$ (The men in function of the landscape). This title already inverts what me mentioned for the modern times: the landscape in function of men. In his book Cabrera talks about the theory of sound as a form of intangible landscape perception. In many of his poems Cabrera describes that border between the land and the sea, creating with words landscape pictures. Yet what he narrates with regards to the intangible is the landscape perception of a man living in an island. Islanders always perceive the sea even when not visible, thanks to its sound, so an intangible experiential value. The second inspiration comes from the Spanish poet Manuel Padorno and his reflection on the desvio, the retour, in the Oxford Dictionary defined as "A long or roundabout route that is taken to avoid something or to visit somewhere along the way". Juanma affirms that to focus on specific aspects of the landscape you need a desvio, it is not possible anymore to apply a unique Brunelleschi perspective, a unique human centered perspective. Your retour can be set according to different perspective and criteria.

Those assumptions and examples of inspiring author made us reflect on the fact that in modern times the recovered centrality of the man after the medieval times was coincident with both humanistic and science development. There was just one perspective on humanity, that of Princes, artists, architects and philosophers, with precise ideas for the goodness of the people that were reflected in the landscape. This perspective was of course celebrating the humankind and their intellect and the way this can govern and dominate the world through the progress of science and arts as powerful communication tools. 


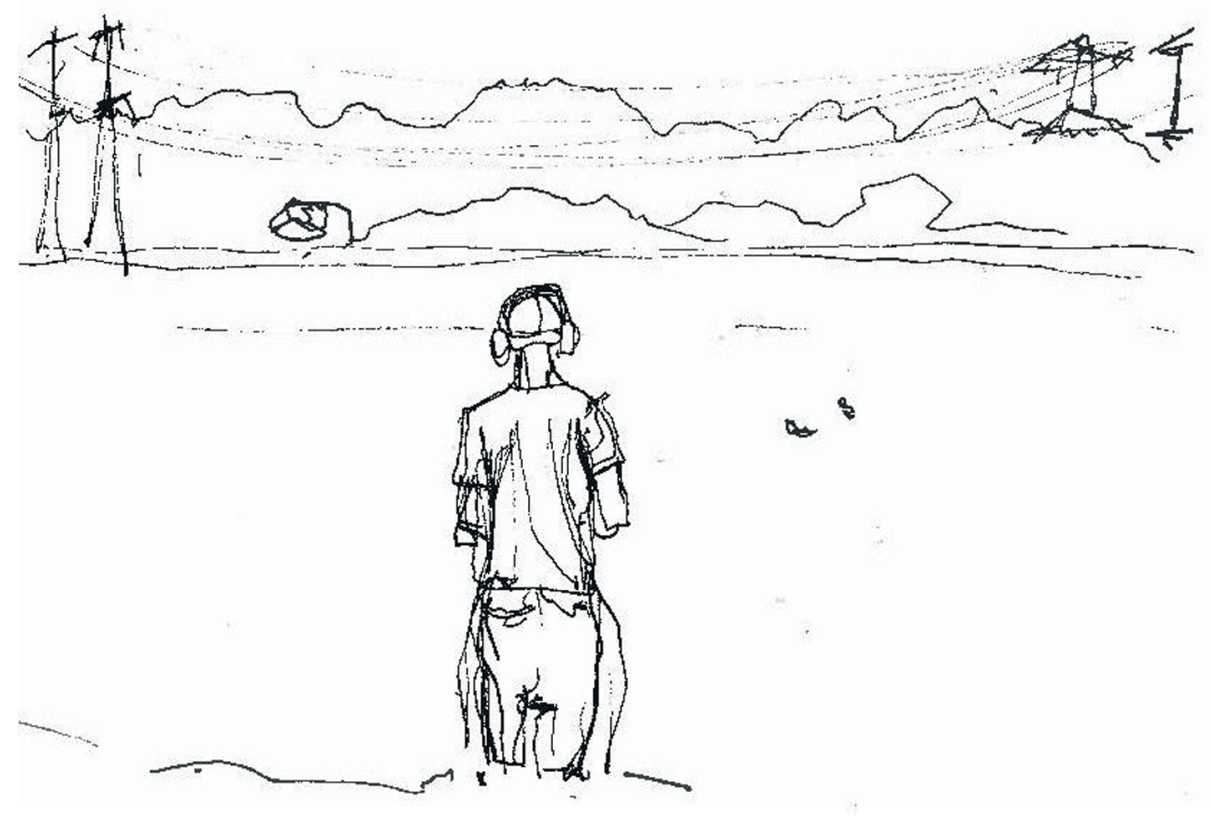

Fig. 1 - A landscape we investigated in 2021 edition.

The Noorder-JI plass in Amsterdam. This was a former excavation site to collect the sand necessary to realize the Amsterdam motorway ring in the north west quadrant. The site was then flooded and now is a lake rich in nature and offering recreation. We spent an afternoon in the site observing the experiential value of the landscape and this was impressed by this sketch by Mirjam Keovoet, a landscape architect working as officer at the Municipality, showing a guy listening to music and fishing. 
02

Nowadays the current socio-cultural pluralism advocated by critical and human geography and the democratization of decisions in every field result in multiple perspectives and criteria that may be in contrast between the central and the local levels. This is evident when we face 21stcentury transitions as the energy one. The progress towards a carbon free future do not always coincide with people aspirations for the development of their landscapes: there the intangible landscape values deserve extra care. Here it is that a central idea like the decarbonisation can be interpreted per different perspectives or retours and consider innumerous criteria. Whenever we think about our research field, energy transition and available space, perspectives can be as much as every experiential landscape value potentially expressed, because depending on how people interpret and make use of free space.

Continuing our conversation, we asked to Juanma if the intangible experiential values of the landscape can confer the spatial qualification of public space also to vacant and abandoned spaces when temporary used by people. He confirmed it and continued that for this reason a landscape project cannot be a simple technique, an administrative practice. The project is not a technique, the intangible values must be a design principle, and not a design outcome, this terpret them in the knowledge phase first and design process then. The experiential value is not just an emotion, it is a project theme, the quality of the project depends on the capacity to perceive the use that citizens already do of the landscapes. The quality of the relationships that we create through the project becomes then a key design parameter. The landscape must be designed according to a desvio, yet contemporary urban design doesn't want to understand that the landscape is not just a surface to be composed but the people who is living on it. My reflections come from experiences in designing the landscape as practiotioner. The intangible can be understood only through a good design practice and landscape architecture must provide continuous answers to the intangible.

We acknowledge Juan Manuel to have opened such insights, and to have referred to poets and writers, that can further stimulate the keeping on of our research. Indeed, in his answers we found a strong alignment with our research findings of the last three years. The current planning indeed focuses on technology itself, this is functional to the decarbonization, so it is in favour of the environment where we live, yet it brings just one idea, a very centralized idea that does not foresee the experiential and intangible values of the landscape at the local scale and levels. Each time we involved the regional strategy planners in our landscape immersions we real- 


\section{Note}

ized that these technicians had located wind turbines in those landscapes but they had never been there before and in the end enjoyed so much experiencing those 'not official' landscapes. We need therefore to further investigate design thinking for the local design implementation of energy regional planning that can put landscape experiential values first, and we can do it better if we involve planners in our landscape immersions in a sort of reciprocal feedback effect.

\footnotetext{
${ }^{1}$ Picchi P., Oudes D., Stremke S. 2020, Linking research through design and adult learning programs for urban agendas: a perspective essay, «Ri-Vista. Research for landscape architecture», vol. 18, n. 1, pp. 198-213.

2 Perec G. 1974, Species of Spaces and Other Pieces, Penguin Books, London, pp. 1-96.

${ }^{3}$ Debord G. E. 1955, Introductionà une critique de la géographie urbaine, «Les lèvres nues», n. 6, pp. 288-292.

${ }^{4}$ See the 21st century challenges through the garden metaphor as in Venturi Ferriolo M. 2019, Oltre il giardino, Einaudi, Torino.

${ }^{5}$ Juan Manuel Palerm is the current President of UNISCAPE, he is landscape architect owner of the atelier Palerm\&Tabares de Nava arch., he is full Professor of Architecture an landscape design by ULPGC, Gran Canaria in Spain, POLIMI, Milan, and IUAV Venice in Italy. ${ }^{6}$ Cabrera P. G., El hombre en función del paisaje. Obras completas, 4, 201-209.
} 